\title{
ПИТАННЯ КРИМІНОЛОГІЧНОГО ЗАБЕЗПЕЧЕННЯ ЕКОНОМІЧНОї БЕЗПЕКИ УКРАЇНИ
}

\author{
СВДОКІМЕНКО Світлана Вікторівна - доктор юридичних наук, доцент, \\ завідувач відділу підвищення кваліфікації Харківського науково-дослідного \\ інституту судових експертиз ім. засл. проф. М.С. Бокаріуса \\ СВДОКІМЕНКО Сергій Анатолійович - кандидат юридичних наук, \\ доцент кафедри кримінально-правових дисциплін та адміністративного права \\ Харківського університету
}

DOI:10.32782/NP.2020.2.10

В статье очерчень основнье вопросъи криминологического обеспечения экономической безопасности Украинъл. Определена его структура и сущность, охарактеризовано содержание функииональных составляющих. Сосредоточено внимание на особенностях нормативно-правового, организачионноуправленческого, информационного и научнометодического компонента обеспечения экномической безопасности Украинъ.

Ключевъие слова: экономическая безопасность, развитие экономики, угрозъ экономической безопасности, защита, криминологическое обеспечение, экономическая преступность.

\section{Постановка проблеми}

Сьогоднішній рівень економічної безпеки України характеризується як низький, що зумовлено наявністю великої кількості внутрішніх та зовнішніх економічних загроз. У сучасній науковій літературі вчені - кримінологи ведуть мову про криміналізацію економіки, тобто соціальний деструктивний процес, у межах якого легальні економічні інститути набувають рис тіньових та кримінальних у зв'язку 3 поширенням правопорушень або злочинів економічної спрямованості, корисливо-мотивованих посягань на законну діяльність суб'єктів господарювання, що призводять до негативних наслідків у вигляді матеріальної шкоди $[1$, c. 4]. Це в сучасних умовах є першочерго- вими проблемами державного рівня, розробленням яких займались такі вчені, як П. П. Андрушко, О. М. Бандурка, В. С. Батиргареєва, А. М. Бойко, В. В. Василевич, В. О. Глушков, В. В. Голіна, Н. О. Гуторова, І. М. Даньшин, Т. А. Денисова, О. М. Джужа, А. П. Закалюк, А. Ф. Зелінський, О. М. Костенко, О. М. Аитвинов, О. М. Аитвак, М. І. Мельник, С. Л. Стрельцов, В. Я. Тацій, В. О. Туляков та інші. Означені науковці досліджували економічну безпеку країни в різних $\dddot{1 і ̈ ~ п р о я в а х . ~}$ Незважаючи на достатньо високий рівень наукової уваги до цієї проблематики, питання, пов'язані саме із кримінологічним забезпеченням економічної безпеки, потребують більш детального розгляду. Адже економічні процеси вимагають системного моніторингу, а постійно виникаючі загрози економічній безпеці - потребують вчасного виявлення та швидкої нейтралізації. Тому формування ефективної системи економічних відносин, стійкої до негативних зовнішніх впливів і водночас інтегрованої до міжнародного економічного простору, є одним із найважливіших та актуальних завдань національної політики держави.

Цілісна система забезпечення економічної безпеки $є$ основою ефективного функціонування будь-якої країни, а кримінологічна складова у цій системі $є$ центральною ланкою. Це обумовлює актуальність даної публікації. 
Метою статті $є$ окреслення структури та основних функціональних складових системи кримінологічного забезпечення економічної безпеки України.

\section{Виклад основного матеріалу}

Економічний та соціальний стан в Україні за 2013-2020 роки змінився у бік погіршення через реалізацію загроз національній безпеці практично у всіх іiі сферах, але найбільш негативний вплив обумовлений економічною, внутрішньополітичною, воєнною та інформаційною сферою. Через перевагу в системі суспільних відносин саме безвідповідальності та недостатніх важелів становлення соціальної відповідальності зросла кількість економічних та соціальних втрат [2, с. 173].

Ключовою умовою нової якості економічного зростання є забезпечення економічної безпеки шляхом системної протидії організованій економічній злочинності та «тінізації» економіки на основі формування переваг легальної господарської діяльності та водночас консолідації інституційних спроможностей фінансових, податкових, митних та правоохоронних органів, виявлення активів організованих злочинних угруповань та їх конфіскації.

Тобто протидія економічній злочинності в ситуації, що склалася, є основою для забезпечення економічної безпеки в Україні та, відповідно, підняття рівня їі соціально-економічного розвитку.

Як відомо, протидія злочинності - це особливий інтегрований, багаторівневий об'єкт соціального управління, що є різноманітною за формами діяльністю відповідних суб'єктів (державних, недержавних органів та установ, громадських формувань і окремих громадян), які взаємодіють у вигляді системи різнорідних заходів, спрямованих на пошук шляхів, засобів та інших можливостей ефективного впливу на злочинність з метою зниження інтенсивності процесів детермінації злочинності на всіх рівнях, нейтралізації дії їі причин та умов для обмеження кількості злочинних проявів до певного рівня [3,c. 277].

Кримінологічне забезпечення слід розглядати як створення умов, у результаті яких має настати сприятлива для діяльності суб'єктів протидії злочинності ситуація або їх множина. Воно є допоміжною діяльністю у вигляді створення сприятливих умов для здійснення відповідними суб'єктами (державними, недержавними органами та установами, громадськими формуваннями і окремими громадянами) впливу на злочинність 3 метою зниження інтенсивності процесів детермінації злочинності, нейтралізації дії іiї причин та умов для обмеження кількості злочинних проявів до певного рівня [4, с. 187].

3 огляду на те, що систему органів протидії економічній злочинності становлять переважно державні органи, основним завданням яких є протидія економічній злочинності, тобто органи, які діють у межах кримінального судочинства, а саме: Служба безпеки України, органи прокуратури, Департамент захисту економіки Національної поліції України, Державна фіскальна служба, Національне антикорупційне бюро України, казначейська служба, Державна служба фінансового моніторингу України, Державна аудиторська служба України та Рахункова Палата, відповідно забезпечення умов для ефективної їх діяльності у сфері протидії економічній злочинності і $\epsilon$ завданням кримінологічного забезпечення.

При цьому напрямками кримінологічного забезпечення $\epsilon$ сукупність заходів нормативно-правового, організаційноуправлінського, інформаційного та науково-методичного характеру, які є елементами системи кримінологічного забезпечення протидії економічній злочинності. Надалі пропонуємо розглянути зміст кожного із вказаних напрямків по відношенню до забезпечення економічної безпеки України.

Нормативно-правове забезпечення. Протидія злочинності, економічній в тому числі, базується на законодавчій основі, 


\section{Кримінальне право, кримінальний процес та криміналістика}

якою керуються суб'єкти відповідної діяльності при здійсненні покладених на них обов'язків. Фактично воно є створенням матеріальних і процесуальних умов для забезпечення ефективності діяльності суб'єктів протидії економічній злочинносTi.

До правових засобів протидії злочинності належать такі: 1) Конституція України; 2) міжнародні договори, ратифіковані ВРУ; 3) кодифіковані нормативно-правові акти; 4) Закони України; 5) підзаконні акти; 6) акти застосування норм права;7) судовий прецедент і судова практика.

Актуальність дослідження цього напрямку кримінологічного забезпечення обумовлена реформуванням та постійними законодавчими змінами у правовому регулюванні економічних процесів країни.

Основу нормативно-правового забезпечення протидії злочинності складають правове регулювання, правові засоби, правові явища та правовий вплив, за допомогою яких суб'єкти протидії злочинності реалізують відповідні заходи.

Невідповідність і суперечливість нормативних актів щодо регулювання економічних процесів призвели до серйозних прорахунків, допущених на початкових етапах реформ, послаблення системи державного регулювання і контролю, що разом із недосконалістю правової бази, відсутністю дієвої державної політики у соціальній сфері, занепадом духовності i моралі суспільства стали основними чинниками, що сприяли зростанню злочинності, особливо іiі організованих форм, а також корупції.

У провідних західних країнах концепція національної економічної безпеки $\epsilon$ теоретичною основою економічної політики країни. Вона утворюється спільними зусиллями вчених та фахівців певних державних структур і відбиває в концентрованому вигляді погляди на сутність змін та шляхи забезпечення (захисту) національних економічних інтересів.
Аналізуючи стан законодавчого забезпечення діяльності з протидії економічній злочинності, слід зауважити, що суттєвим його недоліком $є$ відсутність уніфікованого нормативно-правового акта, яким було 6 врегульовано державну політику у сфері протидії економічній злочинності.

Перехід до інноваційної моделі соціально-економічного розвитку робить особливо актуальною цілеспрямовану діяльність щодо забезпечення економічної безпеки країни та іiі громадян на основі єдиної державної стратегії як нормативно-правового акта. Саме такий правовий документ стає тією методологічною основою, на базі якої відбувається правове регулювання економічних відносин у країні. Він повинен систематизувати та інтегрувати всі конкретні закони економіко-правового плану. У такому разі можна сподіватися на взаємодоповнюючу, синхронну дію низки законів в єдиному напрямі і з певною ефективністю. В Україні, як відомо, спостерігається зворотний ефект [5, с. 281].

У зв'язку з чим, як справедливо пропонує ряд науковців, нагальною є необхідність розроблення та затвердження на державному рівні обгрунтованої Концепції економічної безпеки України, реалізація якої створить можливості ефективного захисту й реалізації національних економічних інтересів на основі цілеспрямованого впливу на сучасні загрози зовнішнього та внутрішнього походження [6, с. 14].

Організачійно-управлінсъке забезпечення. Ефективність діяльності відповідних суб'єктів протидії економічній злочинності напряму залежить від якості організаційного забезпечення.

Адже організація 6 вирішальною ланкою будь-якої діяльності. Суть організації полягає у тому, щоб кожний знаходився на своєму місці та виконував належні обов'язки. Ця дуже проста істина $є$ у той же час основою науки та практики управління, у тому числі профілактики злочинів. У сфері протидії злочинності, як і в інших сферах, управління та організація 
органічно поєднані між собою і прямо залежать одне від одного [7, с. 63].

Організаційно-управлінська сфера кримінологічного забезпечення - це цілеспрямована діяльність 3 організації процесу протидії злочинності, який складається із системи різнорідних заходів, що здійснюються у визначених формах та із застосуванням спеціальних методів; складовими такої багатоаспектної діяльності є її мета, суб'єкти та об'єкти, принципи, форми й методи їі реалізації. Результат такої діяльності виражається у створенні впорядкованої та взаємоузгодженої системи суб'єктів протидії злочинності (державних, недержавних органів та установ, громадських формувань та окремих громадян), функціонування яких обумовлено досягненням спільної мети [4, с. 195].

Інбормачійне забезпечення правоохоронної діяльності $\epsilon$ якісно необхідним підгрунтям для підвищення ефективності протидії злочинності. Від якості та адекватності інформації про потенційні і реальні загрози економічній безпеці країни залежить результативність та ефективність протидії їм, недопущення та мінімізації негативних наслідків.

Інформаційне забезпечення протидії економічній злочинності є структурно складною діяльністю відповідних органів, спрямовану на одержання, використання, зберігання, обробку, передачу кримінологічно значущої інформації, 3 метою вирішення основних завдань протидії злочинним проявам, що становлять собою загрозу економічній безпеці країни.

Сучасний розвиток інформаційних технологій змінюе і суспільство, і злочинність як соціальне явище. Інформаційно-мережеві відносини в різних сферах життєдіяльності набувають усе більшої актуальності. Значного поширення отримують кіберзлочини, що мають значну специфіку скоєння, профілактики. 3 огляду на це інформаційне забезпечення протидії економічній злочинності має відповідати вимогам часу. Aле на сьогодні слід констатувати явну невідповідність між рівнем розвитку інформаційних систем та технологій із сучасними потребами правоохоронних органів у цій сфері.

Крім того, недостатнім є фінансове та кадрове забезпечення, у зв'язку з чим слід вказати на безсистемність і неузгодженість у зборі інформації, їі розосередженість по різних відомствах. 3 метою вдосконалення інформаційно-аналітичного забезпечення протидії економічній злочинності необхідним вбачається створення єдиної державної інтегрованої інформаційної системи для забезпечення постійного моніторингу економіки з метою подальшого швидкого виявлення і ефективного прогнозування загроз економічній безпеці.

Науково-методичне забезпечення. Ефективність протидії злочинності залежить від ступеня наукового забезпечення та аналітичного супроводження на всіх рівнях, інтенсивності взаємодії вчених i практиків різних дотичних галузей науки у справі формування узгодженого інтегрованого цілісного наукового продукту. Негативні процеси і тенденції, які відбуваються в Україні, вимагають постійного наукового відстеження, глибокого і детального дослідження криміногенної обстановки, внесення відповідних коректив у стратегію і тактику протидії злочинності [8, с. 6].

Виняткову роль у цьому процесі відіграють кримінологічні дослідження. Вони є неоціненними щодо своєчасного виявлення прогалин у нормативно-правовому регулюванні питань, що стосуються гарантування економічної безпеки, вирішення проблем правозастосовної практики.

Одним 3 основних призначень кримінологічних досліджень є практика їх реалізації у правоохоронній діяльності. Саме кримінологічна наука шукає науково обгрунтовані шляхи вирішення проблемних питань стосовно злочинності та заходів протидії їй. Вони знаходять своє втілення в розробці практичних рекомендацій iз приводу організаційних і методичних аспектів протидії злочинності в цілому, i економічній, зокрема. Ці дослідження 


\section{Кримінальне право, кримінальний процес та криміналістика}

дають підстави для здійснення таких видів діяльності, як: кримінологічний моніторинг; кримінологічне прогнозування; кримінологічне планування протидії злочинності. Вони лежать в основі визначення тенденцій розвитку економічної злочинності, обгрунтовують прогнозування та планування заходів протидії їй, визначення основних напрямів їі розвитку.

Враховуючи викладене, безсумнівною є необхідність інтенсифікації наукової розробки широкого кола актуальних питань протидії економічній злочинності як одній з основних загроз економічній безпеці держави.

Вказані напрямки кримінологічного забезпечення протидії економічній злочинності є ключем до гарантування економічної безпеки країни. Вони є елементами однієї системи і, відповідно, реалізовуватись повинні у взаємодії та взаємозв'язку між собою.

\section{Висновки та перспективи подальших досліджень}

Розгорнута характеристика процесів криміналізації економіки, виявлення кримінологічних закономірностей та детермінант формування кримінальних практик у сфері господарювання дадуть змогу більш повно зрозуміти розвиток цих процесів у взаємозв'язку з легальними економічними інститутами, що дозволить у подальшому більш ефективно впроваджувати інституційний механізм протидії економічній злочинності [1, с. 2].

Економічна безпека держави потребує постійного різностороннього спостереження і вивчення 3 метою своєчасного виявлення та ефективної нейтралізації негативних чинників, які продукують загрози iii стабільному розвитку. Кримінологічне забезпечення економічної безпеки України - це динамічний процес, який вимагає комплексного та системного підходу, його гостра практична необхідність безсумнівна, а планомірне здійснення окресленої вище сукупності заходів нормативно-правового, організаційно-управлінського, інформаційного та науково-методичного характеру створить сприятливі умови для діяльності суб’єктів протидії економічній злочинності. А це одне з першочергових завдань держави і воно не може бути вирішене в межах сучасних застарілих форм і методів діяльності суб'єктів.

Назріла гостра практична необхідність у розробці науково обгрунтованих новітніх механізмів гарантування економічної безпеки з урахуванням тих ризиків та загроз, які існують на сьогодні.

Тільки довгострокова концептуально вивірена система кримінологічного гарантування економічної безпеки може бути запорукою подолання кризи в означеній сфері і забезпечить успіх цієї діяльності.

\section{入ітература}

1. Маслій I. В. Інституційний механізм протидії криміналізації економіки: кримінологічне дослідження: автореф. дис. ... канд. юрид. наук: 12.00.08. Одеса, 2015. 229 c.

2. Грищенко I. М., Новікова О. Ф. Економічна безпека України: монографія / за ред. В. Г. Федоренка. К. : Вид-во : ТОВ «ДКС центр». 2017. 462 с.

3. Кримінологічний довідник: довідкове видання/за наук. ред. д-ра юрид. Наук, професора, академіка НАПрН України Бандурки О. М.; за заг. ред. д-ра юрид. наук, професора Джужі О. М. і д-ра юрид. наук, професора Аитвинова О. М. Харків: Золота миля, 2013. 412 с.

4. Кримінологія. Академічний курс / Кол. авторів ; за заг. ред. О. М. Аитвинова. К.: Видавничий дім «Кондор», 2018. 588 c.

5. Гриценко О. А., Макуха С. М. Економічна безпека держави: сутність та напрями формування : монографія / за ред. д-ра екон. наук, проф. А. С. Шевченко. Х.: Право, 2009. - 312 с.

6. Богма О. С. Аналіз рівня економічної безпеки України за основними складовими. Науковий вісник Ужгородського національного університету. Випуск 8, частина 1. 2016. С. 11-14 


\section{АНОТАЦІЯ}

у статті окреслено основні питання кримінологічного забезпечення економічної безпеки України. Визначено його структуру та сутність, охарактеризовано зміст бункиіональних складових. Зосереджено увагу на особливостях нормативно-правового, організаиійно-управлінсъкого, інбормачійного та науково-методичного компоненту забезпечення економічної безпеки України.

Ключові слова: економічна безпека, розвиток економіки, загрози економічній безпечі, захист, кримінологічне забезпечення, економічна злочинність.

7. Бандурка О. М. Стратегія і тактика протидії злочинності : монографія /О. М. Бандурка, О. М. Аитвинов. Х. : НікаНова, 2012.

8. Бандурка О. М., Аитвинов О. М. Злочинність як об'єкт феноменологічного аналізу. Право і безпека. 2015. № 3 (58).C. 6-10.

\section{SUMMARY}

The author of the article has outlined the main issues of criminological provision of economic security of Ukraine. Its structure and essence have been determined; the content of functional components has been characterized. Particular attention has been paid to the specific features of regulatory, organizational and managerial, informational, scientific and methodological component of ensuring the economic security of Ukraine.

It has been concluded that the economic security of the state requires constant multilateral monitoring and research in order to timely identification and effective neutralization of the negative factors that perform threats to its stable development. Criminological provision of Ukraine's economic security is a dynamic process that requires a comprehensive and systematic approach, its acute practical necessity is unquestionable, and the systematic implementation of the outlined set of legal, organizational, managerial, informational, scientific and methodological measures will create favorable conditions for the activities of subjects of combating economic crime. It is one of the primary tasks of the state and it cannot be solved within the existing outdated forms and methods of subjects' activity.

It has been reasonably proved that there is currently an urgent practical need to develop scientifically sound new mechanisms for ensuring economic security, taking into account the risks and threats that exist today. Nevertheless, only a longterm conceptually verified system of criminological provision of economic security can be a guarantee of overcoming the crisis in this area and ensure the success of this activity.

Key words: economic security, economic development, threats to economic security, protection, criminological provision, economic crime. 